\title{
SERUM TNF ACTIVITY HAD NO INFLUENCE ON MEGAKARYOCYTIC EMPERIPOLESIS IN THE RAT BONE MARROW
}

\author{
Masaharu Tanaka, Yoshiya Aze, Yutaka Shichino, and Tsuneo Fujita \\ Fukui Institute for Safety Research, Ono Pharmaceutical Co., Ltd.
}

\begin{abstract}
The relationship between megakaryocytic emperipolesis in the bone marrow and lipopolysaccharide (LPS)-induced tumor necrosis factor (TNF) was investigated in adrenalectomized or dexamethasone (Dex)-treated rats. Adrenalectomized rats were injected LPS intravenously at a single dose of $0.5 \mu \mathrm{g} / \mathrm{kg}$ body weight $48 \mathrm{~h}$ after the operation, and Dex-treated rats were given LSP at a dose of $0.5 \mathrm{mg} /$ $\mathrm{kg}$ body weight $1 \mathrm{~h}$ after the Dex-treatment. Serum TNF activity markedly increased in the adrenalectomized rats $(3279.3$ units $/ \mathrm{ml})$, but reduced in the Dex-treated rats $(227.3 \mathrm{units} / \mathrm{ml}) 1 \mathrm{~h}$ after LPS-treatment. Megakaryocytic emperipolesis was not influenced by these treatments $24 \mathrm{~h}$ after LPSadministration. Thus, LPS-induced serum TNF activity could not increase megakaryocytic emperipolesis. (J Toxicol Pathol 8 : 151 154, 1995)
\end{abstract}

Key words : Emperipolesis Lipopolysaccharide, Tumor necrosis factor

Megakaryocytic emperipolesis, i.e. entrance of hematopoietic cells into the megakaryocyte cytoplasm, was observed in lipopolysaccharide (LPS)treated rat bone marrow ${ }^{1,2}$. This phenomenon should be distinguished from phagocytosis, because entering cells retain normal structures in megakarocytes ${ }^{3-5}$. Tavassoli ${ }^{6}$ suggested that the high demand for cell delivery from the bone marrow into peripheral blood might make blood cells take a transmegakaryocyte path to enter the blood circulation and that megakaryocytic emperipolesis was related to cellular traffic across the marrow-blood barrier. Parmley et al. ${ }^{7}$ proposed that an undefined insult to the marrow, increased megakaryocyte turnover or death, may contribute to the neutrophil emperipolesis by megakaryocytes. De Pasquale et $a l^{8}$ also reported that the megakaryocyte cytoplasm might provide a sanctuary for normal granulocytes under an unfavorable bone marrow environment. Some

田中雅治 阿瀬善也 七野 裕 藤田常夫

Accepted for publication: February 28, 1995

Mailing address: Masaharu Tanaka, Fukui Institute for Safety Research, Ono Pharmaceutical Co., Ltd., 50-10, Yamagishi, Mikuni-cho, Sakai-gun, Fukui 913, Japan. investigators have been proposing several hypotheses of the cause of megakaryocytic emperipolesis, but the exact mechanism is still unknown.

On the other hand, LPS brings about broad biological activities through the effects of macrophage-derived mediators such as $\mathbf{T N F}^{\mathbf{9}-12}$. Therefore, it is reasonable to consider that LPSinduced TNF may increase the incidence of megakaryocytic emperipolesis. However, the effect of LPS-induced TNF on megakaryocytic emperipolesis has not been studied. This study was carried out to clarify this point.

Forty-eight 6-week-old male rat of Sprague Dawley strain were purchased from Japan Clea Inc., Osaka. Animals were placed in a hanging stainless wire cage in a barrier sustained animal room at a temperature of $23 \pm 2^{\circ} \mathrm{C}$ and a humidity of $55 \pm 10 \%$ with $12 \mathrm{~h}$ of light and darkness (from $8: 00$ to $20: 00$ ). They were fed a standard pellet diet (CE-2, CLEA Osaka) and tap water ad libitum. Rats were divided into 8 groups. In Groups 1 and 2, animals were adrenalectomized bilaterally and were given saline (Group 1) or 0.5 $\mu \mathrm{g} / \mathrm{kg}$ body weight of LPS (from Escherichia coli, Dibco Laboratories, U.S.A.) (Group 2) $48 \mathrm{~h}$ after 


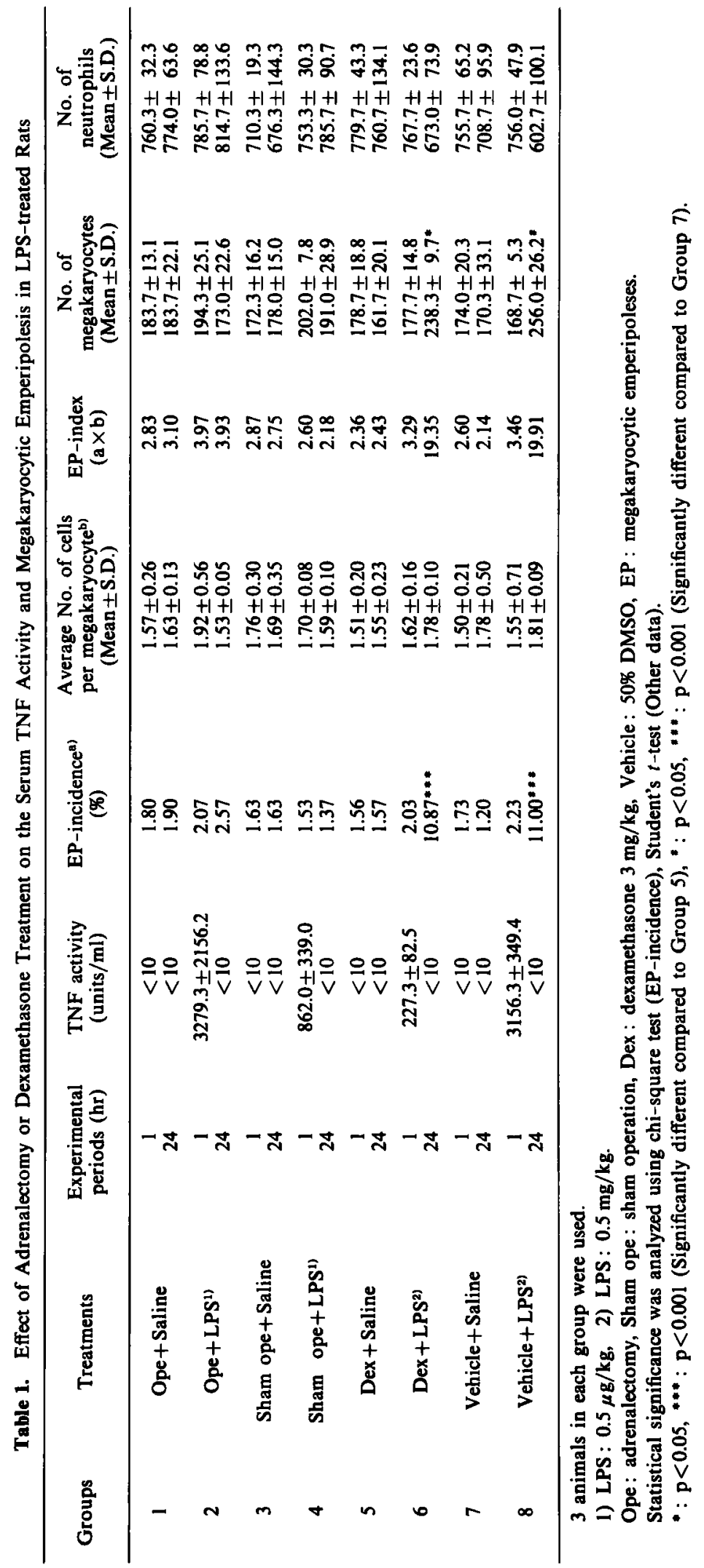


the operation, respectively. Animals in Groups 3 and 4 (Sham-operated groups) were given LPS or saline in same way. Then adrenalectomized rats were maintained with $0.9 \%$ saline solution as drinking water.

Animals in Groups 5 and 6 were intraperitoneally administered $3 \mathrm{mg} / \mathrm{kg}$ body weiht of Dex, glucocorticoid (SIGMA Chemical Co., U.S.A.) dissolved in $50 \%$ dimethylsulfoxide (DMSO) solution (vehicle). These rats were given saline or $0.5 \mathrm{mg} / \mathrm{kg}$ body weight of LPS $1 \mathrm{~h}$ after Dex-treatment, respectively. It is well known that adrenalectomy enhances the susceptibility of rats to endotoxin ${ }^{13}$, and serum TNF activity markedly increased in the adrenalectomized rats as Zuckerman et al. reported in mice ${ }^{12}$. On the other hand, it was demonstrated that Dex-treatment inhibited the induction of TNF synthesis of macrophages by LPS in vitro ${ }^{9}$.

Animals in Groups 7 and 8 were treated with vehicle and received LPS or saline in the same way, respectively. Three rats in each group were sacrificed at 1 and $24 \mathrm{~h}$ after LPS injection, respectively. Blood samples for TNF assay were collected from the abdominal aorta of each animal under ether anesthesia. Serum TNF assay was done according to the procedure of Flick and Gifford $^{14}$. The femoral bone including the bone marrow was removed and fixed in $10 \%$ neutral buffered formalin. Following decalcification, the tissues were prepared routinely for paraffin sections and stained with hematoxylin and eosin (HE). Emperipolesis index and the number of hematopoietic cells were counted according to the previous methods ${ }^{2}$.

The results are shown in Table 1. Serum TNF level markedly increased in Group 2 (3279.3 units $/ \mathrm{ml}$ ) as compared with Group 4 (862.0 units/ $\mathrm{ml})$ on $1 \mathrm{~h}$, but it could not be detected $(<10$ units $/ \mathrm{ml}$ ) at $24 \mathrm{~h}$. On the other hand, serum TNF activity was not detected ( $<10$ units $/ \mathrm{ml}$ ) in Groups 1 and 3 during the experimental periods. At $24 \mathrm{~h}$, although not significant, megakaryocytic emperipolesis showed a trend to increase in Group 2 (2.57\%) as compared with Group 4 (1.37\%). In addition, emperipolesis index and the number of hematopoietic cells showed no significant difference between the adrenalectomized and sham-operated rats with LPS-treatment during the experimental periods. On the other hand, serum TNF level markedly decreased in Group 6 (227.3 units $/ \mathrm{ml}$ ) as compared with Group 8 (3156.3 units $/ \mathrm{ml})$ at $1 \mathrm{~h}$, but it could not be detected $(<10$ units $/ \mathrm{ml}$ ) at $1 \mathrm{~h}$ in both groups. In Groups 5 and 7 serum TNF activity was not detected $(<10$ units $/ \mathrm{ml}$ ) during the experimental periods.

Megakaryocytic emperipolesis significantly increased in the LPS-treated groups (Group 6, $10.87 \%$; Group 8, 11.00\% : $p<0.001)$ as compared with the saline control groups (Group 5, 1.57\%; Group 7, 1.20\%) at $24 \mathrm{~h}$. The number of megakaryocytes also increased in the LPS-treated groups (Group 6, 238.3 cells ; Group 8, 256.0 cells ; p $<$ $0.05)$ as compared with the saline control groups (Group 5, 161.7 cells; Group 7, 170.3 cells) at 24 h. But there was no significant difference between the Dex and non-Dex group in LPS-treated rats. The number of neutrophils in the bone marrow showed no significant difference in both groups during the experimental periods.

As mentioned above, serum TNF activity was markedly enhanced in the adrenalectomized rats with LPS-treatment, but emperipolesis incidence, number of entering cells per megakaryocyte and emperipolesis index showed no increase in these animals. On the other hand, serum TNF activity was considerably reduced in the Dex-treated rats with LPS-treatment, but these stated parameters also showed no changes. Thus, it seems that serum TNF activity has no direct effect on megakaryocytic emperipolesis. However, in our previous study, megakaryocytic emperipolesis showed a positive correlation with the numbers of megakaryocytes (host cells) and mature neutrophils (entering cells) in the bone marrow of rats treated with LPS $^{2}$. Therefore, there is still a possibility that some cytokines such as megakayocyte or neutrophil proliferating factors will produce emperipolesis. Further studies on granulocyte-colony stimulating factor and thrombopoientin will be needed to elucidate this point.

Acknowledgement: The authors would like to thank Dr. Kunio Doi (Department of Biomedical Science, Faculty of Agriculture, The University of Tokyo) for reviewing the manuscript and his valuable suggestions. 


\section{References}

1. Tanaka, M. Aze, Y, and Fujita, T : Megakaryocytic emperipolesis in the rat bone marrow induced by lipopolysaccharide. J Vet Med Sci 56 : 1173-1175, 1994.

2. Tanaka, $\mathbf{M}$, Aze, $Y$, and Fujita, $\mathbf{T}$ : The relationships between increased emperipolesis index and severe hematopoietic cell hyperplasia in the bone marrow of LPS-treated rats. J Toxicol Pathol 7 : 371-377, 1994.

3. Humble, JG Jayne, WHW, and Pulvertaft, RJV : Biological interaction between lymphocytes and other cells. Br J Haematol 2: 283-294, 1956.

4. Tavassoli, $\mathrm{M}$ : Emperipolesis by megakaryocyte in blood loss. Br J Haematol 49: 660-661, 1981.

5. Thile, J, Krech R, Choritz, H, and Gerogii, A : Emperipolesis-peculiar feature of megakaryocytes as evaluated in chronic myeloproliferative diseases by morphometry and ultrastructure. Virchows Arch B 46 : 253-263, 1984.

6. Tavassoli, $M$ : Modulation of megakaryocyte emperipolesis by phlebotomy: Megakaryocytes as a component of marrow-blood barrier. Blood Cells 12 : 205-216, 1986.

7. Parmley, RT, Kim, TH, Austin, RL, Avarado, CS, and Ragab, AH : Emperipolesis of neutrophils by dysmorphic megakaryocytes. Am J Hematol 13 :
303-311, 1982.

8. De Pasqual, A, Paterlini, P, Quaglino, D, and Quaglino, D : Emperipolesis of granulocytes within megakaryocytes. Br J Haematol 60 : 384-386, 1985.

9. Beutler, B, Krochin, N, Milsbark, IW, Luedke, C, and Cermi, A : Contros cachectin (tumor necrosis factor) synthesis: mechanisms of endotoxin resistance. Science 232 : 977-980, 1986.

10. Cybulsky, ME, Chan, MK, and Movat, HZ: Acute inflammation and microthrombosis induced by endotoxin, IL-1, and TNF and their implication in gram-negative infection. Lab Invest 58 : 365-378, 1988.

11. Issekutz, AC and Bhinji, S : Role of endotoxin in the leukocytic infiltration occupying $E$. coli inflammation. Infect Immun 36 : 558-566, 1982.

12. Zuckerman, ST, Shellhass, J, and Butler, LD : Differential regulation of lipopolysaccharide-induced interleukin 1 and tumor necrosis factor synthesis: effects of endogenous and exogenous glucocrticoids and the role of the pituitary-adrenal axis. Eur J Immunol 19 : 301-305, 1989.

13. Levine, $\mathbf{S}$ and Sowinski, $\mathbf{R}$ : Endotoxin toxicity in rats is enhanced by tilorone. Proc Soc Exp Biol Med 151 : 329-332, 1976.

14. Flick, DA and Gifford, GE : Comparison of in vitro cell cytotoxic assays for tumor necrosis factor. J Immunol Methods 68 : 167-175, 1984. 